Vijayakumar, A.N. (2021). Relativity of Indian Stock Market with Exchange Rate, Gold and Crude Oil. Copernican Journal of Finance \& Accounting, 9(4), 101-118. http://dx.doi.org/10.12775/ CJFA.2020.024

\author{
A.N. ViJaYAKumar* \\ Indian Institute of Plantation Management Bengaluru
}

\title{
RELATIVITY OF INDIAN STOCK MARKET WITH EXCHANGE RATE, GOLD AND CRUDE OIL
}

Keywords: co-integration, crude oil, exchange rate, gold, stock market.

\section{J E L Classification: G15.}

Abstract: Stock market return is a motivating factor to investor in investment and portfolio decisions. Markets attracts domestic and foreign investments in anticipation of higher returns considering several parameters. These returns are influenced with economic, taxation and geo-political factors. Investment decision at market discounts with fluctuations of oil, exchange rate and gold. India being the largest consumer, the demand for crude oil and gold has been increasing and lead to higher import bill impacting fluctuations on exchange rate (USD-INR). Investor's investment decisions at market discounts with volatility of oil, exchange rate and gold. This study with causal research method using 25 years of data administered Johansen co-integration and Vector Error Correction Model to explore the relative impact of exchange rate, crude oil and gold on Indian stock market. The study finds presence of long run relationship of exchange rate, gold and crude oil with market returns and absence of short run relationship. The findings shall facilitate in understanding the impact of fluctuations and investment decisions to benefit from Indian stock market.

Date of submission: January 9, 2021; date of acceptance: March 4, 2021.

* Contact information: v.kumariipmb@gmail.com, Indian Institute of Plantation Management Bengaluru, Jnanabharathi campus, Mallathalli - Post, Bangalore 560056, India, phone: +91-9844361528; ORCID ID: https://orcid.org/0000-0003-2319-2132. 


\section{INTRODUCTION}

Stock market of India is one of the leading Asian markets considering the reputation of market regulations and returns. It has been influenced by social, political and economic factors such as inflation rate, exchange rates, flow of foreign investments, political stability, growth of gross domestic product, liquidity and government policies of India and other influencing countries. Gold and Crude oil are the largest traded commodities and used as an important financial asset in portfolio management by investors and fund managers. Crude oil, apart from using as a fuel, is also an input for wide gamut of industries and subsequent price movement's influences related prices of lubricants, fertilizers, transportation and petrochemicals. Hence, prices of oil are a major concern to all stakeholders and economies of the world. It is also one of the influencing factors causing instability on stock market and its returns. India is one among the largest importing country of crude oil imported $82.1 \%$ of total consumption during the year 2016-17 (Dalei, Roy \& Gupta, 2017). International transactions of settlement are largely through US dollars, hence, the greater demand for oil leads to deflation of Indian currency (Jain \& Biswal, 2016).

India is one of the largest jewellery market in the world consumes gold as an input to meet domestic and international processing requirements and is expected to increase around 33\% by 2021. Gold in India is largely imported hence; valuation of Indian currency shall weaken against US dollar resulting appreciation of its value in terms of Indian rupee. The impact of rise in oil prices, foreign capital and remittances by non-resident Indians working in Gulf countries also influencing a positive relation of crude oil and stock market valuation. Similarly, decrease in valuation of Indian currency against US dollar resulting to fall in market returns and higher import bills for crude. India being the net importing country to both crude oil and gold settles exchange transactions through US dollars. Hence, any changes in exchange rate of USD-INR have impacts on multiple economic indicators including stock market returns. This fluctuation in valuation of gold, exchange rate and market returns motivated to explore causal effect of relativity. India has two popular stock exchanges facilitating to raise share capital and trade of listed securities. The sensitivity index of Bombay stock exchange consisting of 30 most traded Indian companies' forms indices known as Sensex. This paper shall be considering Sensex as a barometer for understanding the Indian stock market returns as one of the vari- 
able. The remaining part of this paper has been presented in following sections. Section 2 describes literature review, section 3 elucidates research methodology, section 4 presents results and discussions and finally section 5 concludes the research study with findings.

\section{LITERATURE REVIEW}

This study reviewed scholastic research on gold, crude oil, exchange rate, and stock market returns from national and international sources of repute. The stock prices and exchange rates play a significant role in influencing investor's confidence and development of the economy. Bhunia and Pakira (2014) and Ranjusha, Devasia and Nandakumar (2017) analysed the impact of exchange rate and gold on Sensex employing Granger causality and Johansen co-integration test. The study finds existence of long run integration and no causal effect with exchange rate and gold. Geete (2016) assessed the effect of gold and dollar prices on stock exchange indices. The multiple regression analysis found positive correlation with gold and nifty whereas negative relationship between dollar and nifty. The relationship of gold on Karachi Stock Exchange (KSE) and Bombay Stock Exchange (BSE) were analysed by Bilal, Noraini Bt, Haq, Khan and Naveed (2013). The study found non-existence of long-run relationship amongst monthly average prices of gold and KSE stock index; whereas, a significant long-run relationship occurred between BSE stock index and average gold prices. Similarly, Narang and Singh (2012) argued absence of long run association and non-causal relation between prices of gold and Sensex. The dependence between global crude oil prices and stock indices in economies of fast emerging Asian countries were analysed by Mishra and Debasish (2019). The analysis revealed asymmetric effects with stock index returns and crude oil prices indicating better performance of Asian countries by means of higher production and consumption of goods and services. Studies of Sathyanarayana, Harish and Gargesha (2018); Najaf and Najaf (2016); Naifar and Al Dohaiman (2013) analysed volatility of crude oil prices and its influence on Indian stock market index. The statistical tests disclose that changes in crude prices have an impact on Sensex. It was also found that stock market index shares a direct relationship with crude oil, indicating raise in crude prices caused Sensex to go up and vice-versa. The short and long run asymmetric impact of oil prices, gold prices and their related volatilities on stock prices of emerging economies were 
analysed by Raza, Syed, Aviral Kumar and Shahbaz (2016). The results indicated non-linearity and absence of long run coefficients between the selected variables indicating higher volatility and decrease in stock prices. Similarly, Rahman and Mustafa (2018) explored effect of gold and crude oil prices on US stock market variations and found there exists a long run convergence among the variables. The long and short-term impact on gold and stock returns were analysed and found existence of co-integration relationship and non-existence of short-run relationship between the selected variables (Bhuyan \& Dash, 2018).

The interdependencies of oil, gold, exchange rate and stock market were examined to identify linkages in Indian scenario by Mohanamani, Preethi and Latha (2018). The study found negative linkage of crude oil prices and exchange rate with gold. It was also observed that exchange rate is highly influenced by changes in both oil and gold prices. Similarly, Sujit and Kumar (2011) found presence of co-integration amongst selected variables but Rastogi (2016) argued there exists long term association. The relationship between oil prices, Nifty and BSE energy index were analysed and found absence of long run integration between the variables by Sharma, Giri, Vardhan, Surange, Shetty and Shetty (2018). Bildirici and Turkmen (2015) analysed co-integration and causal relationship among oil and precious metals of gold, silver and copper. The statistical test revealed there exists a bi-directional relationship of oil, gold and silver. On the other hand Sari, Hammoudeh and Soyta (2010) argued that there exists weak long-run equilibrium relationship. The co-integration and non-liner causality amongst international gold, crude oil and Indian stock market were examined by Bouri, Jain, Biswal and Roubaud (2017) and found positive impact of implied volatility with the selected variables. Siddiqui and Seth (2015) assessed the relation of oil prices on market returns of India and found absence of integration and causality of oil prices with index. The co-integration relationships of gold price, crude oil price, exchange rates, Sensex and Nifty were analysed by Bhunia (2013) and found they are closely interlinked with long term relationship. It was also argued that increase in crude oil prices lead to increase in production costs that will affect both stock prices and cash flows. Interactive association amongst gold, crude oil prices and NT-US dollar exchange rate were examined and found these variables are remain considerably independent from one another by Chang, Huang and Chin (2013). The dynamic interactions among oil, gold prices, exchange rate and the stock market in Indian context were analysed by Jain and Biswal (2016); Ingalhalli, Poornima and Reddy (2016). The empirical results found decline in crude oil and gold prices causes 
fall in value of Indian currency. Ingalhalli, Poornima and Reddy (2016) initiate that there exists only unidirectional relationship among these variables.

The studies on impact of macroeconomic elements on stock markets were also found during scholastic review. The influence of macroeconomic determinants such as Inflation, rate of interest, exchange rate, industrial production index, money supply, silver, gold and crude oil prices on the Indian stock market indices were analysed by Venkatamuni Reddy, Nayak and Nagendra (2019) and Patel (2012). The statistical results revealed long run equilibrium relation and a causal relation between all macroeconomic factors and stock market indices. In addition, it was also found gold price, exchange rate and interest rate are positively correlated with four indices, however, crude oil price and silver price have positively correlated with three indices. Sekaran and Krishnamoorthy (2016) analysed integration considering macro-economic variables on BSE index. The results revealed Chinese Yuan Renminbi, export of goods value, gold, inflation, silver and US Dollar has influenced BSE sensex. Whereas, oil prices and Euro currency does not have a significant influence on BSE Sensex. The association between BSE Sensex with industrial production (IIP), inflation, gold, interest rate, rate of exchange, foreign institutional investment (FII) and supply of money were investigated by Mishra (2018) and found existence of causal relationship. Rakesh, Raju and Basavangowda (2016) studied the impact of currency fluctuations and found effect on Indian stock market as compared to Euro and Pound. The integration of stock prices and exchange rates were examined and found co-integration and bidirectional relationship among stock price and exchange rates in Asia by Fauziah, Moeljadi and Ratnawati (2015). The presences of long memory in stock liquidity and returns of Indian equity market were examined by Bala and Gupta (2020) from the Indian context and confirmed presence of long memory in returns of all indices. Bidias-Menik and Tonmo (2020) tested predictive power of the implied forward rate of the term structure of interest rates at Africa. The study revealed that implicit forward rate does not have a significant predictive power in African countries. Volatility persistence of stock return in the market during pre and post meltdown were observed by Nageri (2019). This study considering return on the exchange disclosed high volatility magnitude after the meltdown but low volatility magnitude before the meltdown. The above scholastic evidences reviewed impact of crude oil, gold, interest rates, Index of Industrial Production (IIP), exchange rates, inflation, Foreign Intuitional Investments (FII) and money supply on Indian stock market. However, the findings are mystifying and there is a need for 
clarity considering the recent economic developments on Indian market with a longer period of data. This dearth of scholastic literature motivated author to study relativity of stock market returns on exchange rate, gold and crude oil to add fresh insights to the existing domain of knowledge.

\section{OBJECTIVE}

The objective is to determine relative impact of Indian currency exchange rate, gold and crude oil on Indian stock market in the short and long run.

\section{RESEARCH METHODOLOGY}

The study based on empirical data adopted causal research method with secondary sources of monthly data for the period of 25 years from 1993 to 2018 considering 1200 observations. This study used Currency exchange rates (USD/ INR), Crude oil and Gold as independent variable and Indian stock market returns as dependant variable. The study collected secondary data of gold, crude oil and Sensex from web sources of New York Mercantile Exchange and Bombay Stock Exchange to ensure authenticity and accuracy. In the first step, stationarity of data using Augmented Dicky Fuller test has been checked. Subsequently, lag order selection criteria have been identified with the help of Akaike Information Criteria of data variables at level. Johansen co integration test is administered to check the existence long term association of identified independent and dependent variables. The VAR model with VECM environment and Wald test is employed to understand long and short term relationship of independent variables on market returns. After the satisfaction of results derived from the model, the study checked residual diagnostics.

Augmented Dickey Fuller (ADF) test is used with the following regression equation:

$$
\begin{aligned}
& \Delta y_{t}=a+\alpha y_{t-1}+\sum_{i=1}^{k} b_{i} \Delta y_{t-i}+\varepsilon_{t} \\
& \Delta y_{t}=a+\beta t+\alpha y_{t=1}+\sum_{i=1}^{k} b_{i} \Delta y_{t-i}+\varepsilon_{t}
\end{aligned}
$$

The unit root in $y_{t}$ where $\Delta y_{t-i}$ is the lagged difference to accommodate serial correlation in the errors, $\varepsilon_{t} \cdot k$ is the appropriate lag length. 
Johansen co-integration validated long-run relationship between the variables at level. Hence, VAR model with VECM environment have been employed to understand the casual relationship. VECM model is a restricted VAR used with nonstationary series are known to be co-integrated. The co-integrating equation is as under:

$$
y_{2, t}=\beta y_{1, t}
$$

The corresponding VEC model is

$$
\begin{aligned}
& \Delta y_{1, t}=\alpha_{1}\left(y_{2, t-1}-\beta y_{1, t-1}\right)+\epsilon_{1, t} \\
& \Delta y_{2, t}=\alpha_{2}\left(y_{2, t-1}-\beta y_{1, t-1}\right)+\epsilon_{2, t}
\end{aligned}
$$

The coefficient $\alpha_{i}$ measures speed of adjustment at i-th endogenous variable towards the equilibrium. The study using Wald test examined significance of explanatory components in a model. The Wald test statistic is as under:

$$
W_{t}=\frac{\left[\hat{\theta}-\theta_{0}\right]^{2}}{1 / I_{n}(\widehat{\theta})}=I_{n}(\hat{\theta})\left[\hat{\theta}-\theta_{0}\right]^{2}
$$

Where:

$\hat{\theta}=$ Maximum Likelihood Estimator (MLE),

$I_{n}(\hat{\theta})=$ expected Fisher information (evaluated at the MLE).

The study used Breusch - Godfrey Serial Correlation LM Test to determine existence of serial correlation of residuals under the developed model. This is an autocorrelation test used to check errors in the model. This statistics is ascertained by an auxiliary regression equation as:

$$
y_{t}=X_{t} \beta+\epsilon_{t}
$$

Where, $\epsilon$ indicates errors.

The study also used Breusch - Pagan - Godfrey test to check validity of heteroscedasticity in the developed model. 


$$
\sigma_{t=\sigma^{2}}^{2} h\left(z_{t}^{\prime} \alpha\right)
$$

Where, $z_{t}$ indicates vector independent variable. This vector contains regressors from the original least square regression, it is tested by completing an auxiliary regression of the squared residual of the original equation on $\left(1, z^{t}\right)$.

Subsequently, Jarque Bera Test is administered for analysing normality of residuals. The test statistics measures difference of skewness and kurtosis of normal distribution series. It is computed as:

$$
\text { Jarque Bera }=\frac{N}{6}\left(S^{2}+\frac{(K-3)^{2}}{4}\right)
$$

Finally, the stability of OLS model was tested using CUSUM test. This test is a cumulative sum portrayed at 5\% critical line. Under this test, the plotted line should reside within the two measured lines otherwise the instability of test shall be noticed.

\section{RESUltS AND DiscusSIONS}

The study focussing on its intended objective found optimal lag order criteria for developing VAR model. Statistical outcome is shown in table 1.

Table 1. Lag order selection criteria

\begin{tabular}{|c|c|c|c|c|c|c|}
\hline \hline Lag & Log L & LR & FPE & AIC & SC & HQ \\
\hline \hline 0 & -5450.965 & NA & $1.98 \mathrm{e}+11$ & 37.36278 & 37.41314 & 37.38295 \\
\hline 1 & -3647.696 & 3544.783 & 955232.3 & 25.12120 & $25.37304^{*}$ & 25.22208 \\
\hline 2 & -3609.701 & 73.64718 & $821696.4^{*}$ & $24.97056 *$ & 25.42385 & $25.15213^{*}$ \\
\hline 3 & -3601.386 & 15.89021 & 866241.2 & 25.02319 & 25.67796 & 25.28546 \\
\hline 4 & -3587.002 & 27.09363 & 876136.4 & 25.03426 & 25.89049 & 25.37723 \\
\hline 5 & -3570.893 & 29.90061 & 875893.2 & 25.03351 & 26.09121 & 25.45718 \\
\hline 6 & -3556.188 & $26.89188 *$ & 884303.7 & 25.04238 & 26.30155 & 25.54675 \\
\hline 7 & -3544.378 & 21.27464 & 910910.1 & 25.07108 & 26.53171 & 25.65615 \\
\hline 8 & -3533.288 & 19.67225 & 943248.5 & 25.10471 & 26.76681 & 25.77048 \\
\hline
\end{tabular}


Table 1. Lag...

\begin{tabular}{|c|c|c|c|c|c|c|}
\hline Lag & $\log L$ & LR & FPE & AIC & SC & HQ \\
\hline \multicolumn{7}{|c|}{$\begin{array}{l}\text { Note }-* \text { indicates selected lag order by criterion } \\
\text { LR: LR test statistic sequential modified (each test at } 5 \% \text { level) } \\
\text { FPE: indicates Final prediction error } \\
\text { AIC: Akaike information criterion } \\
\text { SC: Schwarz information criterion } \\
\text { HQ: Hannan-Quinn information criterion }\end{array}$} \\
\hline
\end{tabular}

S o u r c e : authors' own calculations using E-views.

The table 1 portrays, value under Akaike information criteria (AIC) of 24.97056, is lesser than other lag selection criteria. The study, therefore, selects AIC criteria of 2 lags. This selected 2 lags shall be used for co-integration test and at VAR model.

\section{TEST OF STATIONARITY}

The study checked stationarity of selected independent and dependant variables and found results as shown under table 2 .

Table 2. Test of stationarity

\begin{tabular}{|c|l|c|c|c|c|}
\hline \multirow{2}{*}{ SI. No } & \multicolumn{2}{|c|}{ Variable (log) } & \multicolumn{2}{|c|}{ At the level } & \multicolumn{2}{c|}{ At first difference } \\
\cline { 3 - 6 } & & T-statistic & P - value & T - statistic & P - value \\
\hline \hline 1. & Crude Oil & -1.681562 & 0.4396 & -8.347013 & 0.0000 \\
\hline 2. & Gold & -0.631655 & 0.8600 & -4.149046 & 0.0010 \\
\hline 3. & Exchange rate (USD/INR) & 0.942455 & 0.7737 & -4.004071 & 0.0016 \\
\hline 4. & Sensex & -9.73271 & 0.6374 & -10.31464 & 0.0000 \\
\hline \hline
\end{tabular}

S o u r c e : authors' own calculations using E-views.

The aforementioned table 2 depicts test of stationarity with T-statistics and $P$ value at the level and first order. The $P$ value of crude oil at the level 0.4396 whereas at the first difference, the variables became stationary showing P value of 0.0000 . Similarly, the value of variable Gold at level is 0.8600 whereas, at first difference it became 0.0010 indicating stationarity. The exchange rate 
variable converted to stationarity at the first difference with the $\mathrm{P}$ value of 0.0016 . From the above process, variables became stationary at the first difference were found to be satisfactory and essential for further analysis.

\section{TEST OF Co-INTEgRATION}

The study used prices of oil, gold, exchange rate and monthly returns from one of the Indian exchange indices such as Sensex of Bombay Stock Exchange. The table 3 indicates statistical output of Johansen co-integration test.

Table 3. Unrestricted Co integration Test (trace)

\begin{tabular}{|l|c|c|c|c|}
\hline \hline \multicolumn{1}{|c|}{$\begin{array}{c}\text { Hypothesized } \\
\text { No. of CE(s) }\end{array}$} & Eigenvalue & $\begin{array}{c}\text { Trace } \\
\text { Statistic }\end{array}$ & $\begin{array}{c}\mathbf{0 . 0 5} \\
\text { Critical Value }\end{array}$ & Prob.** \\
\hline \hline None $*$ & 0.233395 & 103.6983 & 47.85613 & 0.0000 \\
\hline At most 1 & 0.047716 & 24.76069 & 29.79707 & 0.1702 \\
\hline At most 2 & 0.033215 & 10.23972 & 15.49471 & 0.2627 \\
\hline At most 3 & 0.000698 & 0.207266 & 3.841466 & \\
\hline Trace test indicates 1 cointegrating at the 0.05 level & & \\
\hline$*$ rejection of hypothesis at the 0.05 level & & \\
\hline$* *$ MacKinnon-Haug-Michelis (1999) p-values & \\
\hline
\end{tabular}

S o u r c e : authors' own calculations using E-views.

The aforementioned table 3 indicates that the $\mathrm{P}$ value is less than 0.05 at $95 \%$ confidence level advising for rejecting null hypothesis of no co-integration of independent variables with dependant variable (Indian stock market returns). The study, therefore, accepts alternative hypothesis of existence of co-integration of independent variables with dependant variable having a $\mathrm{P}$ value more than 0.05 . This indicates long-run association amongst the variables of crude oil, gold, exchange rate and the Indian stock market. 


\section{Vector ErRor Correction Model}

The study after finding the existence of co-integration of independent variables with dependant variables administered Vector Error Correction Model using 2 lags, as per AIC lag order selection criteria. Accordingly, the following equation has been obtained with the developed Error Correction model:

$$
\begin{aligned}
D(R S N S X)= & C(1) *(\operatorname{RSNSX}(-1)+0.0232049340022 * \operatorname{USIN}(-1) \\
& +0.000921902212722 * C L(-1)-0.000579761608521 * G L(-1) \\
& -1.87566064959)+C(2) * D(\operatorname{RSNSX}(-1))+C(3) * D(R S N S X(-2)) \\
& +C(4) * D(\operatorname{USIN}(-1))+C(5) * D(\operatorname{USIN}(-2))+C(6) * D(C L(-1)) \\
& +C(7) * D(C L(-2))+C(8) * D(G L(-1))+C(9) * D(G L(-2))+C
\end{aligned}
$$

\begin{tabular}{|c|c|c|c|c|}
\hline \multicolumn{5}{|c|}{ Dependent Variable: D(RSNSX) } \\
\hline \multicolumn{5}{|c|}{ Method: Least Squares } \\
\hline \multicolumn{5}{|c|}{ Sample (adjusted): 1993M07 2018M03 } \\
\hline \multicolumn{5}{|c|}{ Included observations: 297 after adjustments } \\
\hline \multicolumn{5}{|c|}{$\mathrm{D}(\mathrm{RSNSX})=\mathrm{C}(1) *(\operatorname{RSNSX}(-1)+0.0232049340022 * \mathrm{USIN}(-1)+$} \\
\hline \multicolumn{5}{|c|}{$0.000921902212722 * C L(-1)-0.000579761608521 * G L(-1)-$} \\
\hline \multicolumn{5}{|c|}{$1.87566064959)+C(2) * D(\operatorname{RSNSX}(-1))+C(3) * D(\operatorname{RSNSX}(-2))+C(4)$} \\
\hline \multicolumn{5}{|c|}{$* \mathrm{D}(\mathrm{USIN}(-1))+\mathrm{C}(5) * \mathrm{D}(\mathrm{USIN}(-2))+\mathrm{C}(6) * \mathrm{D}(\mathrm{CL}(-1))+\mathrm{C}(7) * \mathrm{D}(\mathrm{CL}(-2))+\mathrm{C}(8)^{*} \mathrm{D}(\mathrm{GL}(-1))+\mathrm{C}(9) * \mathrm{D}(\mathrm{GL}(-2))+\mathrm{C}(10)$} \\
\hline & Coefficient & Std. Error & t-Statistic & Prob. \\
\hline$C(1)$ & -0.878069 & 0.102668 & -8.552475 & 0.0000 \\
\hline$C(2)$ & -0.118640 & 0.086014 & -1.379313 & 0.1689 \\
\hline$C(3)$ & -0.011344 & 0.060229 & -0.188340 & 0.8507 \\
\hline$C(4)$ & -0.677760 & 0.464040 & -1.460564 & 0.1452 \\
\hline$C(5)$ & 0.265412 & 0.471521 & 0.562885 & 0.5740 \\
\hline$C(6)$ & 0.020208 & 0.096190 & 0.210087 & 0.8337 \\
\hline
\end{tabular}

The study using above equation with least squares method estimated the VAR model as under.

Table 4. Model output 
Table 4. Model...

\begin{tabular}{|l|c|c|c|c|}
\hline \hline & Coefficient & Std. Error & t-Statistic & Prob. \\
\hline \hline$C(7)$ & 0.041096 & 0.095956 & 0.428280 & 0.6688 \\
\hline$C(8)$ & 0.002758 & 0.012718 & 0.216878 & 0.8285 \\
\hline C(9) & 0.005024 & 0.012541 & 0.400599 & 0.6890 \\
\hline C(10) & -0.001986 & 0.418485 & -0.004746 & 0.9962 \\
\hline R-squared & $\mathbf{0 . 4 9 0 5 0 6}$ & Mean dependent var & -0.014913 \\
\hline Adjusted R-squared & 0.474529 & S.D. dependent var & 9.627543 \\
\hline S.E. of regression & 6.978945 & Akaike info criterion & 6.756763 \\
\hline Sum squared resid & 13978.53 & Schwarz criterion & 6.881131 \\
\hline Log likelihood & -993.3793 & Hannan-Quinn criter. & 6.806552 \\
\hline F-statistic & $\mathbf{3 0 . 7 0 0 4 9}$ & $\mathbf{0 . 0 0 0 0 0 0}$ & Durbin-Watson stat & 2.000781 \\
\hline Prob(F-statistic) & & & \\
\hline \hline
\end{tabular}

S o u r c e : authors' own calculations using E-views.

The table 4 depicts co-efficient of $\mathrm{C} 1$ is negative $(-0.878069)$ and significant with $P$ value 0.0000 , i.e., less than 0.05 . This indicates presence of long run relationship from exchange rate (USD/INR), crude oil and gold to Indian stock market returns. It is observed that F - statistics (30.70049) is significant with $P$ value less than 0.05 (0.000000) showing combined influence of independent variables on dependant variable. The value of $\mathrm{F}$ statistics is more important than $\mathrm{R}$ square equivalent to $50 \%$ according to the model.

\section{Short Run CAUSAl RELATIONShiP}

The study using Wald test explored short run causal relationship of exchange rate, crude oil, gold and Indian stock market. Accordingly, the table 5 depicts the Chi-square value with corresponding $\mathrm{P}$ values. The statistical results cannot reject null Hypothesis of no short-run causality and concluded the non-existence of short run causal relationship of exchange rate (USD/INR), crude oil and gold with Indian stock market. 
Table 5. Wald Test

\begin{tabular}{|l|c|c|}
\hline \hline \multicolumn{1}{|c|}{ Variables } & Chi-Square value & P-value \\
\hline \hline Exchange Rate & 2.441209 & 0.2951 \\
\hline Crude Oil & 0.336526 & 0.8451 \\
\hline Gold & 0.228502 & 0.8920 \\
\hline Restrictions are linear in coefficients. & \\
\hline \hline
\end{tabular}

S o u r c e : authors' own calculations using E-views.

\section{Serial Correlation Test}

The study checked validity of OLS model through residual diagnostic test of Breusch-Godfrey Serial Correlation. Accordingly, the observed R square $(0.291429)$ with corresponding probability value $(0.8644)$ is more than $5 \%$. Hence, the null hypothesis - Residuals are not serially correlated, cannot be rejected. The output of results is desirable.

\section{TEST OF HETEROSKEDASTICITY}

The study finds rejection of null hypothesis from the statistical value of observed R square (31.03625) with corresponding probability value $(0.0019)$ being less than 0.05 hence, it finds that residuals are homoscedastic.

\section{TEST OF NORMALITY}

Jarque Bera Normality test finds the p value (0.103) is not significant at the general acceptance level of $5 \%$ (figure 1). Therefore, the study cannot reject null hypothesis, and concludes that residuals are being normally distributed. It is also fulfilling the condition of bell-shaped curve. 
Figure 1. Test of Normality

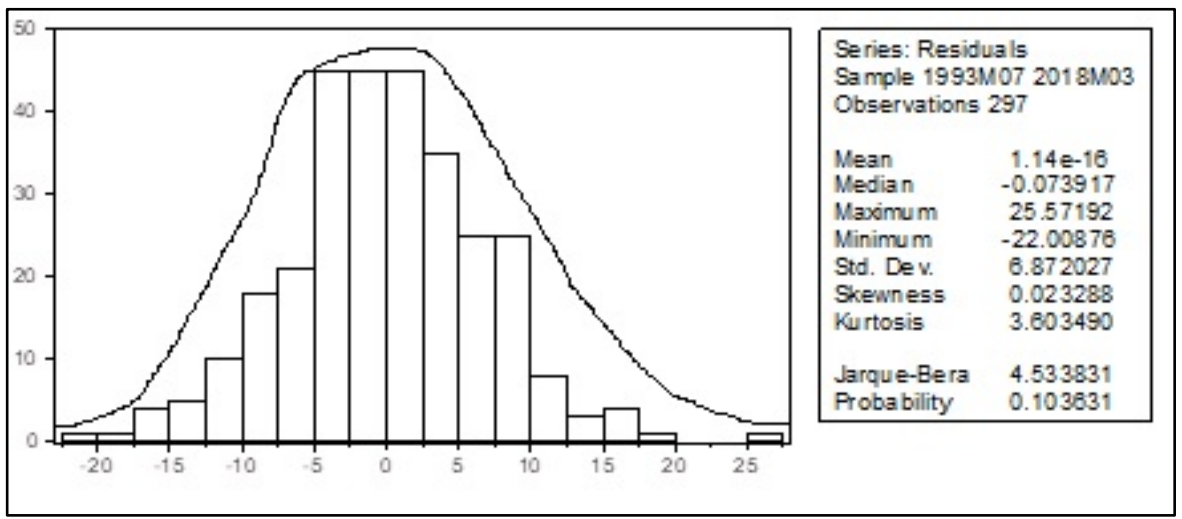

S o u r c e : authors' own calculations using E-views.

\section{StABILITy Test}

Stability of VECM model developed in the study is subjected to CUSUM test. Figure 2 shows that curved line is between +15 and -15 . Hence, the developed VECM model under the study is stable and it is desirable to accept the results.

Figure 2. Stability test

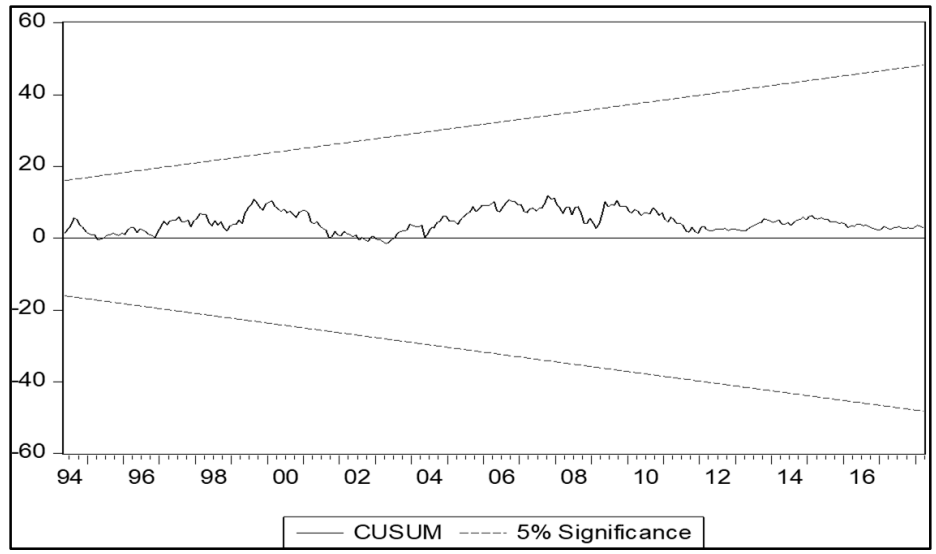

S o u r c e : authors' own calculations using E-views. 


\section{FINDINGS AND ConCLUSION}

Stock market responds to the present and subsequent economic developments and shocks. The potential of earnings by listed companies shall reflect in the index movements. The general economic theory of cost and expected returns attracts investors to divert there investments on potential assets. This study considering shocks of exchange rate, gold and oil on Indian stock market evidenced long-run association of co-movements with the help of Johansen co-integration test. The Vector auto regression with vector error correction model finds long run causal relationship of identified variables on Indian market, Sensex. However, the study did not find the existence of short run causal relationship of exchange rate, oil and gold with Sensex. This research paper validated with economic and investment theory of influencing prices of crude oil, gold and exchange rate of stock market. Thus, increase in crude oil prices and exchange rate (USD/INR) would lead to plunge in returns at Indian stock market in the long run. Similarly, increase in import of gold leads to weakening of Indian rupee and results in declining market returns. This findings of study may be useful to investor and fund managers to develop appropriate strategies for manging the port-folio and investment decisions. Further research studies may consider daily or weekly data of gold, crude oil and exchange rates to estimate impact on market returns and also may compare with developing countries of economical factors to identify opportunities for wealth creation at Indian and other identified stock markets.

\section{Acknowledgement}

"The author is grateful to editor and anonymous reviewers of the journal for their extremely useful suggestions to improve the quality of the paper. Usual disclaimers apply."

\section{Declaration of Conflicting Interests}

The authors declared no potential conflicts of interest with respect to the research, authorship and/or publication of this article. 


\section{REFERENCES}

Bala, A., \& Gupta, K. (2020). Examining the Long Memory in Stock Returns and Liquidity in India. Copernican Journal of Finance \& Accounting, 9(3), 25-43. http://dx.doi. org/10.12775/CJFA.2020.010.

Bhunia, A. (2013). Cointegration and Causal Relationship among Crude Price, Domestic Gold Price and Financial Variables: An Evidence of BSE and NSE. Journal of Contemporary Issues in Business Research, 2(1), 1-10.

Bhunia, A., \& Pakira, S. (2014). Investigating the Impact of Gold Price and Exchange Rates on Sensex: An Evidence of India. European Journal of Accounting, Finance and Business, 2(1), 1-11.

Bhuyan, A.K., \& Dash, A.K. (2018). A dynamic causality analysis between gold price movements and stock market returns: Evidence from India. Journal of Management Research and Analysis, 5(2), 117-124. http://dx.doi.org/10.18231/23942770.2018.0019.

Bidias-Menik, H.P., \& Tonmo, S.G. (2020). Interest rate predictability in some selected African countries. Copernican Journal of Finance \& Accounting, 9(3), 45-60. http:// dx.doi.org/10.12775/CJFA.2020.011.

Bilal, A.R., Noraini Bt, A.T., Haq, I.U., Khan, M.N.A.A, \& Naveed, M. (2013). How Gold Prices Correspond to Stock Index: A Comparative Analysis of Karachi Stock Exchange and Bombay Stock Exchange. World Applied Sciences Journal, 21(4), 485-491. http:// dx.doi.org/10.5829/idosi.wasj.2013.21.4.2870.

Bildirici, M.E., \& Turkmen, C. (2015). Nonlinear Causality between Oil and Precious Metals. Resources Policy, 46(2), 202-211. http://dx.doi.org/10.1016/j.resourpol.2015.09.002.

Bouri, E., Jain, Biswal, P.C., \& Roubaud, D. (2017). Cointegration and Nonlinear Causality amongst Gold, Oil, and the Indian Stock Market: Evidence from Implied Volatility Indices. Resources Policy, 52, 201-206. http://dx.doi.org/10.1016/j.resourpol.2017.03.003.

Chang, H.-F., Huang, L.-C., \& Chin, M.-C. (2013). Interactive Relationships between Crude Oil Prices, Gold Prices, and the NT-US Dollar Exchange Rate-A Taiwan Study. Energy Policy, 63, 441-448. http://dx.doi.org/10.1016/j.enpol.2013.09.029.

Dalei, N.N., Roy, H., \& Gupta, A. (2017). Crude Oil Import of India from Its Major Oil Trade Partner Countries: An Empirical Evidence Using Panel Data Analysis. International Journal of Advanced Research and Development 726(6), 2455-4030.

Fauziah, F., Moeljadi, M., \& Ratnawati, K. (2015). Dynamic relationship between exchange rates and stock prices in Asia, 2009-2013. Journal of Economics, Finance and Accounting, 2(1), 124-124. http://dx.doi.org/10.17261/Pressacademia.201519783.

Geete, V. (2016). A Study on Impact of Gold Prices and Dollar Prices on Stock Market Indices with Special Reference to Sensex Nifty. European Journal of Economic and Business, 1(1), 28-33. http://dx.doi.org/10.20936/EJEB/160105. 
Ingalhalli, V., Poornima B.G., \& Reddy, Y.V. (2016). A Study on Dynamic Relationship Between Oil, Gold, Forex and Stock Markets in Indian Context. Paradigm, 20(1), 83-91. http://dx.doi.org/10.1177/0971890716637706.

Jain, A., \& Biswal, P.C. (2016). Dynamic Linkages among Oil Price, Gold Price, Exchange Rate, and Stock Market in India. Resources Policy, 49, 179-185. http://dx.doi. org/10.1016/j.resourpol.2016.06.001.

Mishra, P. (2018). An Investigation of the Macroeconomic Factors Affecting the Indian Stock Market. Australasian Accounting, Business and Finance Journal, 12(2),71-86. http://dx.doi.org/10.14453/aabfj.v12i2.5.

Mishra, S., \& Debasish, S.S. (2019). The Quantile Dependence between Global Crude Oil Price and Stock Markets in Emerging Asia: Evidence from Major Oil Consuming Nations. Afro-Asian Journal of Finance and Accounting, 9(3), 309-331. http://dx.doi. org/10.1504/AAJFA.2019.100980.

Mohanamani, P., Preethi, D., \& Latha, L. (2018). Dynamic Linkage between Gold, Oil, Exchange Rate and Stock Market Returns: Evidence from India. International Journal of Pure and Applied Mathematics, 119(17), 2567-2580.

Nageri, K.I. (2019). Evaluating volatility persistence of stock return in the pre and post 2008-2009 financial meltdown. Copernican Journal of Finance \& Accounting, 8(3), 75-94. http://dx.doi.org/10.12775/CJFA.2019.013.

Naifar, N., \& Al Dohaiman, M.S. (2013). Nonlinear Analysis among Crude Oil Prices, Stock Markets' Return and Macroeconomic Variables. International Review of Economics and Finance, 27, 416-431. http://dx.doi.org/10.1016/j.iref.2013.01.001.

Najaf, R., \& Najaf, K. (2016). Impact of Crude Oil Prices on the Bombay Stock Exchange. Journal of Business \& Financial Affairs, 5(4), 10-12. http://dx.doi.org/10.4172/21670234.1000216.

Narang, S.P., \& Singh, R.P. (2012). Causal Relationship between Gold Price and Sensex: A Study in Indian Context. Vivekananda Journal of Research, 1, 33-37.

Patel, S. (2012). The effect of Macroeconomic Determinants on the Performance of the Indian Stock Market. NMIMS Management Review, 22.

Rahman, M., \& Mustafa, M. (2018). Effects of Crude Oil and Gold Prices on US Stock Market: Evidence for USA from ARDL Bounds Testin. Finance and Market, 3(1), 1-9. http://dx.doi.org/10.18686/fm.v3.1055.

Rakesh, D., Raju, J.K., \& Basavangowda, K.G. (2016). An Impact of Currency Fluctuations on Indian Stock Market. International Journal of Application or Innovation in Engineering \& Management, 5(6), 146-151.

Ranjusha, N., Devasia, M.D., \& Nandakumar, V.T. (2017). Cointegrating Relation Between Exchange Rate and Gold Price. International Journal of Research-Granthaalayah, 5(10), 263-269. http://dx.doi.org/10.5281/zenodo.1043230.

Rastogi, S. (2016). Gold Price, Crude Oil, Exchange Rate and Stock Markets. International Journal of Corporate Finance and Accounting, 3(2), 1-13. http://dx.doi.org/10.4018/ IJCFA.2016070101.

Raza, N., Syed, J.H.S., Aviral Kumar, T., \& Shahbaz, M. (2016). Asymmetric Impact of Gold, Oil Prices and Their Volatilities on Stock Prices of Emerging Markets. Resources Policy, 49, 290-301. 
Sari, R., Hammoudeh, S., \& Soyta, U. (2010). Dynamics of Oil Price, Precious Metal Prices, and Exchange Rate. Energy Economics, 32(2), 351-362. http://dx.doi.org/10.1016/j. eneco.2009.08.010.

Sathyanarayana, S., Harish, S.N., \& Gargesha, S. (2018). Volatility in Crude Oil Prices and its Impact on Indian Stock Market Evidence from BSE Sensex. SDMIMD Journal of Management, 9(1), 65-78. http://dx.doi.org/10.18311/sdmimd/2018/19997.

Sekaran, M.C., \& Krishnamoorthy, V. (2016). Influence of selected Macro Economics variables on Indian stock market - A study of BSE Sensex. Abhinav National Monthly Refereed Journal of Research in Commerce \& Management, 5(3).

Sharma, A., Giri, S., Vardhan, H., Surange, S., Shetty, R., \& Shetty, V. (2018). Relationship between Crude Oil Prices and Stock Market: Evidence from India. International Journal of Energy Economics and Policy, 8(4), 331-337.

Siddiqui, S., \& Seth, N. (2015). Do Global Oil Price changes affect Indian Stock Market Returns? Journal of Management and Public Policy, 6(2), 29-41.

Sujit, K.S., \& Kumar, B.R. (2011). Study on Dynamic Relationship among Gold Price, Oil Price, Exchange Rate and Stock Market Returns. International Journal of Applied Business and Economic Research, 9(2), 145-165.

Venkatamuni Reddy, A.R., Nayak, R., \& Nagendra, S. (2019). Impact of Macro - Economic Factors on Indian Stock Market- A Research of BSE Sectoral Indices. International Journal of Recent Technology and Engineering, 8(2), 597-602. http://dx.doi. org/10.35940/ijrte.B1110.0782S719. 